\title{
RECENT DEVELOPMENTS IN INDIANA FAMILY LAW: OCTOBER 2015 TO SEPTEMBER 2016
}

\author{
RENA SEIDLER ${ }^{*}$ \\ MARGARET RYZNAR ${ }^{* *}$
}

This Article considers the notable developments in Indiana family law during the survey period of October 1, 2015 to September 30,2016. The Indiana statutes and published appellate cases surveyed in this Article concern same-sex marriage, property division upon divorce, parenting time, child custody and child support, CHINS, as well as the termination of parental rights, spousal maintenance, and jurisdiction and procedure.

\section{SAME-SEX MARRIAGE}

During the survey period, the courts continued to address issues related to same-sex couples. In one such case, a federal district court ruled that both samesex parents should be allowed on their children's birth certificates in the state of Indiana, and an appeal is pending in the U.S. Court of Appeals for the Seventh Circuit. ${ }^{1}$

In another same-sex marriage case during the survey period, an Indiana appellate court considered the termination of a formal registered domestic partnership established in California, where partners had the same rights and obligations imposed upon spouses. ${ }^{2}$ After moving to Indiana, one of the partners was artificially inseminated and gave birth to a child per the parties' joint decision to co-parent a child. ${ }^{3}$ The Indiana appellate court affirmed that the trial court properly recognized the relationship as equivalent to a marriage under California law and therefore properly determined that the non-biological mother was also a legal parent of the child, entitled to parenting time and charged with support obligations. ${ }^{4}$

\section{PROPERTY DIVISION}

On property division matters, an Indiana appellate court affirmed the denial of a wife's attempt to have a 1997 divorce decree set aside based on the husband's alleged fraud during the divorce settlement. ${ }^{5}$ At the time of the divorce,

* Research and Instructional Services Librarian, Indiana University Robert H. McKinney School of Law.

** Associate Professor of Law, Indiana University Robert H. McKinney School of Law.

1. Henderson v. Adams, No. 1:15-cv-00220-TWP-MJD, 2016 WL 3548645 (S.D. Ind. June 30, 2016), clarified in part by No. 1:15-cv-00220-TWP-MJD, 2016 WL 7492478 (S.D. Ind. Dec. 20, 2016).

2. Gardenour v. Bondelie, 60 N.E.3d 1109, 1111 (Ind. Ct. App. 2016), trans. denied, 2017 Ind. LEXIS 186 (Ind. 2017 Mar. 2, 2017).

3. Id.

4. Id. at 1111-12.

5. Waterfield v. Waterfield, 61 N.E.3d 314, 319 (Ind. Ct. App. 2016), trans. denied, 2017

WL 237684 (Ind. Jan. 12, 2017). 
the wife agreed to the settlement, despite her attorney's advice on multiple occasions and in writing that the court would grant her substantially more of the marital net worth than she agreed to accept in the settlement. ${ }^{6}$ The appellate court affirmed that the wife could not recover on her claim of fraudulent misrepresentation of assets in the husband's disclosure statement during settlement negotiations, when there was no discovery conducted at the time of the divorce and the wife entered into the settlement willingly. ${ }^{7}$ The husband was awarded attorney's fees. ${ }^{8}$

\section{PARENTING TIME}

The Indiana Parenting Time Guidelines were adopted in 2001 and later amended. During this survey period, the Indiana Supreme Court issued an order further amending the Indiana Parenting Time Guidelines, which took effect on January $1,2017 .^{9}$

This most recent amendment addressed parenting coordinators by clarifying their role and responsibilities..$^{10}$ A parenting coordinator is a person appointed by a court to conduct parenting coordination, which is defined as:

[A] court ordered, child-focused dispute resolution process in which a Parenting Coordinator ... assist[s] high conflict parties by accessing and managing conflicts, redirecting the focus of the parties to the needs of the child, and educating the parties on how to make decisions that are in the best interest of the child. ${ }^{11}$

In terms of case law during the survey period, an Indiana appellate court affirmed the trial court's decision to deny a father's modification of parenting time and lift the supervision of his visits. ${ }^{12}$ The mother had sole legal and physical custody and the father had supervised visitation, arising after the father was convicted of child seduction of his teenage daughter, who had since been emancipated. ${ }^{13}$ The appellate court affirmed the trial court's decision based on a psychological evaluation of the father, concluding that he had doubtful psychological functioning, was defensive, and showed poor judgment and decision-making. ${ }^{14}$ In the same petition, the father sought to modify his child

6. Id. at 326 .

7. Id. at 327,336 .

8. Id. at 336 .

9. Order Amending Indiana Parenting Time Guidelines, InD. Supreme Court (Sept. 2, 2016), http://www.in.gov/judiciary/files/order-rules-2016-0902-parenting.pdf [https://perma. cc/NXP9-3HKM].

10. Id.

11. Id.

12. Patton v. Patton, 48 N.E.3d 17, 18 (Ind. Ct. App. 2015).

13. Id.

14. Id. at 21-22. 
support based on the daughter's emancipation, which the trial court denied. ${ }^{15}$ The appellate court reversed, finding that the emancipation was a substantial change in circumstances warranting modification. ${ }^{16}$

\section{CHILd CUSTOdY}

The child custody cases that arose during the survey period related notably to interstate custody matters. In one such case, the Indiana Supreme Court affirmed the denial of a mother's petition to modify custody. ${ }^{17}$ When the mother moved cross-country, the father was granted primary physical custody because his living and working conditions were better suited for the child. ${ }^{18}$ The mother petitioned for a modification after she became a stay-at-home mom and better situated to care for the child, while the father's new longer work hours required the child to be in before- and after-school care. ${ }^{19}$ The mother alleged that the child was in an emotionally harmful relationship with her stepsister at the father's home and that the father was not properly notifying her of recommendations from the child's school. ${ }^{20}$ The Indiana Supreme Court affirmed the trial court's finding that the child was adjusted to the school and community in which she lived, that she had typical sibling rivalry with her stepsister, and that modification of custody was not warranted. ${ }^{21}$ The Indiana Supreme Court further concluded that the trial court had acted within its discretion in determining that the father was not in contempt for failing to notify the mother of school recommendations. ${ }^{22}$

In another interstate modification matter, a mother sought modification to become the primary custodian based on allegations that the father was intentionally depriving her of time with the child, harming the mother-child relationship, and damaging the child's relationship with the mother's boyfriend by making the child fearful of him. ${ }^{23}$ The Indiana appellate court found no evidence that the mother-child relationship had been damaged, that the child was fearful of the mother's boyfriend, or that difficulties in scheduling parenting time were not improving. ${ }^{24}$ The appellate court also addressed an attorney fees issue not related to this modification petition. ${ }^{25}$

Finally, the Indiana appellate court affirmed a trial court's order denying a mother's request to relocate with her child to Texas and instead granting the

15. Id. at 22 .

16. Id. at 23 .

17. Steele-Giri v. Steele, 51 N.E.3d 119, 123 (Ind. 2016).

18. Id. at 121 .

19. Id. at 122 .

20. $I d$.

21. Id.

22. Id. at 129.

23. Montgomery v. Montgomery, 59 N.E.3d 343, 348 (Ind. Ct. App. 2016), trans. denied, 2017 Ind. LEXIS 73 (Ind. Feb. 9, 2017).

24. Id. at 352-54.

25. Id. at 354-55. 
father primary physical custody and sole legal custody. ${ }^{26}$ At the time this matter arose, the child was eleven and the parents had shared custody since her birth. ${ }^{27}$ The appellate court agreed with the trial court's consideration of the child's wishes to stay with her father, finding that the trial court was not clearly erroneous in determining that it was not in the child's best interest to relocate and in awarding sole legal custody to the father. ${ }^{28}$

\section{CHILD SUPPORT}

There were several child support cases of note decided during the survey period. One such case arose out of a father's petition to reduce or abate his child support obligation during his incarceration. ${ }^{29}$ The father was sentenced initially in 1988 to a thirty-year prison sentence, ultimately serving ten years with twenty suspended..$^{30}$ His probation was revoked within a year of his release in 1998 and he was imprisoned until May 2009. ${ }^{31}$ His wife filed for divorce in 1998 and a support order was entered. ${ }^{32}$ The father filed a pro se motion to reduce or abate his obligation in 2001, which was denied. ${ }^{33}$ In 2008, the state of Indiana intervened in the ongoing support collection process and referred the matter to a criminal proceeding for arrearages in excess of $\$ 15,000 .^{34}$ At this point, the trial court abated the father's support obligation from 2001-2009, which the State appealed. ${ }^{35}$ The appellate court reversed in favor of the State because the trial court could not retroactively modify child support obligations that had accrued. ${ }^{36}$

In another case, the Indiana Supreme Court affirmed the appellate court's reversal of a trial court decision requiring a father to be held responsible for his daughter's dental school costs. ${ }^{37}$ The case hinged on the father's divorce obligation to pay for the undefined "postsecondary" education of the child. ${ }^{38}$ The Indiana Supreme Court held that "postsecondary" does not include graduate or professional school expenses. ${ }^{39}$

In a case that began with a divorce and child support order in Wyoming, the Indiana appellate court found that a Wyoming court order that the father had no arrearage was entitled to full faith and credit and could not be declared null and

26. Milcherska v. Hoerstman, 56 N.E.3d 634, 635-36 (Ind. Ct. App. 2016).

27. Id. at 635 .

28. Id. at 642 .

29. State v. Gaw, 46 N.E.3d 1278, 1279 (Ind. Ct. App. 2015).

30. Id.

31. Id.

32. Id.

33. $I d$.

34. Id.

35. Id.

36. Id. at 1281 (citing Whited v. Whited, 859 N.E.2d 657, 661 (Ind. 2007)).

37. Allen v. Allen, 54 N.E.3d 344, 349 (Ind. 2016).

38. Id. at 348 .

39. Id. at $348-49$. 
void by an Indiana court. ${ }^{40}$ The Indiana appellate court further vacated the trial court's order that neither parent could claim an income tax exemption for the children. ${ }^{41}$

\section{CHINS AND the Termination of PAREnTal Rights}

Indiana continues to experience heightened levels of CHINS cases, and a number of significant cases arose during the survey period related to CHINS and the termination of parental rights. ${ }^{42}$ In one such case, the Indiana Court of Appeals affirmed the involuntary termination of a father's parental rights when the child had never lived with him and there was no reasonable probability that the child would ever do so. ${ }^{43}$ The father had been incarcerated during the child's entire lifetime, in numerous states, and for numerous offenses. ${ }^{44}$ The appellate court determined that this history suggested future incarcerations for the father and instability for the child if parental rights were not terminated. ${ }^{45}$

The Indiana Supreme Court also addressed the termination of parental rights when the evidence suggested that there was no substantial change in family circumstances since the removal of children from a home. In that case, the mother was not necessarily benefiting from cognitive therapy after a history of mental illness, not taking prescribed medication, and had a history of physically abusing children. ${ }^{46}$ The trial court terminated both parents' rights, but only the mother appealed. ${ }^{47}$ The Indiana Supreme Court affirmed that her parental rights should be terminated. ${ }^{48}$

The Indiana appellate court also terminated parental rights in another case when the parents failed to participate consistently in reunification services ${ }^{49}$ By the time the Department of Child Services (DCS) became involved in this matter, the home was dirty and mouse-infested, the mother tested positive for methamphetamine, and the father refused drug testing, although he admitted marijuana use. ${ }^{50}$ The father continued to refuse drug testing for some time, even

40. Hays v. Hays, 49 N.E.3d 1030, 1031-32 (Ind. Ct. App. 2016).

41. Id. at 1031 .

42. Marilyn Odendahl, Statewide Crisis of CHINS Stretches Judicial Resources, IND. LAW. (May 18, 2016), http://www.theindianalawyer.com/statewide-crisis-of-chins-stretches-judicialresources/PARAMS/article/40371 [https://perma.cc/9LVY-TFJZ].

43. A.M. v. Ind. Dep't of Child Servs. (In re A.G.), 45 N.E.3d 471, 474-75, 480 (Ind. Ct. App. 2015), trans. denied, 44 N.E.3d 1254 (Ind. 2016).

44. Id. at 474 .

45. Id. at $479-80$.

46. N.G., L.C., \& M.C. v. Ind. Dep't of Child Servs. (In re N.G.), 51 N.E.3d 1167, 1171 (Ind. 2016).

47. Id. at 1169.

48. Id. at 1173-74.

49. D.B. v. Ind. Dep't of Child Servs., 61 N.E.3d 364, 374-75 (Ind. Ct. App. 2016), rev'd and remanded sub nom. D.B. v. Ind. Dep't of Child Servs. (In re Bi. B.), 69 N.E.3d 464 (Ind. 2017).

50. Id. at 367 . 
after the mother admitted that both parents had used methamphetamines before driving a car with their children. ${ }^{51}$ Twenty-three of the father's eventual thirtyfive drug screens tested positive for methamphetamines, marijuana, or both. ${ }^{52}$ Additionally, the mother stated that physical altercations between the parents had taken place in front of the children. ${ }^{53}$ The parents' participation in reunification services was sporadic, the father failed to complete a drug program in the allotted time frame, and the couple did not complete the recommended couple's counseling because of the father's refusal to attend after two sessions. ${ }^{54}$ The appellate court concluded that although DCS filed its petitions prematurely, such error was harmless, and parental rights should be terminated because of the reasonable probability that the home situation would not be remedied. ${ }^{55}$ The Indiana Supreme Court reversed and remanded, finding that DCS's failure to allege or prove the necessary waiting period was not harmless error. ${ }^{56}$

In another case, the appellate court reversed a decision that four minor children were CHINS. ${ }^{57}$ DCS had filed its petition based on substantiated allegations that the mother had smoked marijuana while pregnant and that there had been past domestic violence between the mother and the father of one of her children. ${ }^{58}$ Subsequently, the mother passed random drug screenings over a fourmonth period after admitting that she had used marijuana earlier in life and had smoked it on one occasion while pregnant, before knowing that she was pregnant. ${ }^{59}$ Evidence showed that while unemployed, the mother had searched for paid work and scheduled a job interview. ${ }^{60}$ Additionally, the father of one of her children had supported her financially, she received food stamps, and the children always had a home and sufficient clothing and food ${ }^{61}$ Based on this evidence, the appellate court found that the children were not CHINS. ${ }^{62}$

Similarly, the Indiana Supreme Court reversed the decision of both the trial and appellate courts terminating a father's parental rights because the trial court's findings did not support that termination was in the child's best interests. ${ }^{63}$ When the child was removed from the mother's custody due to her drug use, the father requested that the child be placed with him. ${ }^{64}$ Previously, the father had been

51. Id. at 367-68.

52. Id. at 368 .

53. Id. at 368-69.

54. Id.

55. Id. at $372,375$.

56. D.B. v. Ind. Dep't of Child Servs. (In re BI. B), 69 N.E.3d 464, 469 (Ind. 2017).

57. A.M. v. Ind. Dep't of Child Servs. (In re S.M.), 45 N.E.3d 1252, 1256-57 (Ind. Ct. App. 2015).

58. Id. at 1253.

59. Id. at 1253-54.

60. Id. at 1254 .

61. Id.

62. Id. at 1256-57.

63. R.S. v. Marion Cty. Dep't of Child Servs., 56 N.E.3d 625, 628 (Ind. 2016).

64. Id. at 627 . 
incarcerated for several years, although the court found that he had stayed in regular contact with the child. ${ }^{65}$ While incarcerated, the father failed to complete the programs ordered by the court, but he did complete various parenting and self-improvement courses. ${ }^{66}$ As a condition of parole, the father underwent domestic violence counseling, substance abuse evaluation and treatment, and a mental health evaluation. ${ }^{67}$ The Indiana Supreme Court found that the trial court was erroneous in terminating the father's parental rights when the DCS manager, home-based therapist, and guardian ad litem all agreed that the father and child shared a close bond and that visitation with the father was in the child's best interest. ${ }^{68}$

In the next case, the trial court terminated the parental rights of both parents based on a DCS petition, which was appealed by the father and ultimately vacated ${ }^{69}$ The mother had contacted DCS while suffering from mental illness and feeling overwhelmed caring for the child. ${ }^{70}$ The mother was later diagnosed with schizo-effective disorder. ${ }^{71}$ The father appealed the subsequent termination of parental rights, which was based on the trial court's finding that there was a reasonable probability that the conditions necessitating the removal would not be remedied and that it was in the child's best interests to terminate his parental rights. $^{72}$ The Indiana Supreme Court agreed with the father, reversing the judgment of the trial court and remanding for further proceedings. ${ }^{73}$

In another case, the appellate court found that it was error for DCS to use its coercive power to insert itself into a family relationship by obtaining CHINS findings and then circumventing procedure using the CHINS court to modify custody while a conflicting hearing was scheduled. ${ }^{74}$ In the case, DCS had filed a motion to change custody from the mother to the father while simultaneously awaiting a dispositional hearing that would have ordered services for the mother. ${ }^{75}$ The appellate court determined that sole custody to the father should not have been sought before giving the mother a meaningful opportunity to participate in the services recommended by DCS. ${ }^{76}$

In yet another case addressing the actions of DCS, the Indiana appellate court found that DCS violated a mother's due process rights when her children were compelled to be interviewed by DCS without any evidence that these interviews

65. Id. at 626-27.

66. Id. at 627 .

67. Id.

68. Id. at 630-31.

69. A.A. v. Ind. Dep't of Child Servs. (In re V.A.), 51 N.E.3d 1140, 1142 (Ind. 2016).

70. $I d$.

71. Id.

72. Id. at 1143 .

73. Id. at $1143,1151$.

74. In re J.B., 61 N.E.3d 308, 313-14 (Ind. Ct. App. 2016).

75. Id.

76. See id. 
were needed for DCS to carry out its statutory obligation. ${ }^{77}$ The court specifically noted that under the statute, DCS cannot show good cause by simply stating a "need" for an interview with a child to complete an assessment. ${ }^{78}$

\section{SPOUSAL MAINTENANCE}

During the survey period, the Indiana Supreme Court reversed the appellate court and affirmed a trial court's decision denying a man's petition to terminate spousal maintenance after his disabled ex-wife re-married. ${ }^{79}$ The ex-wife had been awarded spousal maintenance in 2007 after twenty-five years of marriage, based on the court's finding that her legal blindness materially affected her ability to support herself. ${ }^{80}$ Both parties had since re-married and their spouses were earning salaries in the workforce, but the ex-wife's income was still limited to her Social Security Disability and her spousal maintenance, while the ex-husband's income had increased. ${ }^{81}$ The Indiana Supreme Court concluded that the changes in the ex-wife's finances were not so substantial as to warrant terminating maintenance, nor had they improved significantly more than her ex-husband's finances. ${ }^{82}$

\section{JURISDICTION \& PROCEDURE}

In the surveyed period, numerous cases arose addressing jurisdiction and procedure. Several decisions were rendered specifically discussing allegations of procedural errors by the trial court. In one case, the mother appealed the trial court's order ceasing all parenting time pending a hearing on DCS's petition to terminate her parental rights. ${ }^{83}$ The Indiana appellate court denied the mother's appeal, determining that the trial court's order was not a final, appealable judgment. ${ }^{84}$

In another matter, the appellate court reversed the trial court's decision to grant a petition for a protective order, finding that the trial court abused its discretion in admitting a child's hearsay statement to his nanny about being inappropriately touched. ${ }^{85}$ The trial court also erred in admitting police opinion that the statement to the nanny was true.$^{86}$ The Indiana Supreme Court granted a

77. B.S. v. Ind. Dep't of Child Servs. (In re F.S.), 53 N.E.3d 582, 599 (Ind. Ct. App. 2016).

78. Id. at 597 (citing Newton v. Yates, 353 N.E.2d 485, 492 (Ind. Ct. App. 1976)).

79. Gertiser v. Gertiser (In re Gertiser), 45 N.E.3d 363, 364-65 (Ind. 2015).

80. Id. at 365 .

81. Id. at 365-66.

82. Id. at 371-72.

83. D.W. v. Ind. Dep't of Child Servs., 52 N.E.3d 839, 840-41 (Ind. Ct. App.), trans. denied sub nom. T.W. v. Ind. Dep't of Child Servs. (In re Chins), 54 N.E.3d 370 (Ind. 2016).

84. Id. at 842 (citing Ramsey v. Moore, 959 N.E.2d 246, 253-54 (Ind. 2012)).

85. Wood v. D.W. ex rel. Wood, 47 N.E.3d 12, 16 (Ind. Ct. App. 2015), vacated sub nom. A.W. v. R.W., 46 N.E.3d 1240 (Ind. 2016), reinstated, A.W. v. R.W., 53 N.E.3d 1182 (Ind. 2016).

86. Id. at 17 . 
petition to transfer and was evenly divided on the disposition of the case. ${ }^{87}$ Consequently, the Court of Appeals decision was reinstated pursuant to Indiana Rule of Appellate Procedure 58(C). ${ }^{88}$

In another case addressing evidence, a child-victim was unable to testify pursuant to the protected-person statute. The Indiana appellate court determined that the trial court properly admitted his videotaped statement and out-of-court statements to a therapist because they were cloaked with sufficient indicia of reliability. ${ }^{89}$ The child was four years old when significant bruising was found on his body, allegedly caused by the mother's live-in boyfriend.$^{90}$ Criminal proceedings were subsequently brought against the boyfriend. ${ }^{91}$ Although the Indiana appellate court found that the trial court erred in admitting the forensic interviewer's expert testimony, it found such error to be harmless ${ }^{92}$ Furthermore, it was not fundamental error for the trial court to have admitted the combined testimonies of the victim's foster parent, family case manager, and therapist. ${ }^{93}$

In a non-parental custody case, the trial court dismissed an aunt and uncle's petition seeking custody of a child based on lack of standing and jurisdiction. ${ }^{94}$ The Indiana Supreme Court reversed because the aunt and uncle had standing to initiate an independent action seeking custody when a CHINS case was pending against the custodial mother. ${ }^{95}$ The court further clarified that while third parties may file such actions in circuit court, the circuit court should abstain from exercising jurisdiction until the final disposition of the CHINS case. ${ }^{96}$

Finally, in a grandparent adoption case, the Indiana appellate court found that the trial court had not abused its discretion in transferring the adoption petition to the county in which there were already several matters related to the case. These matters included a CHINS case, termination of parental rights case, and an adoption case filed by an aunt and uncle. ${ }^{97}$

In sum, during the survey period of October 1, 2015 to September 30, 2016, the work of the Indiana courts and legislators covered various family law topics, ranging from maintenance issues to CHINS cases. Legal questions remain in the field, leaving opportunities for additional clarification in the next survey period.

87. A.W., 53 N.E.3d at 1182 .

88. Id.

89. Norris v. State, 53 N.E.3d 512, 521 (Ind. Ct. App. 2016).

90. Id. at 517 .

91. Id.

92. Id. at 525 .

93. Id. at 526 .

94. M.B. v. S.B., 51 N.E.3d 230, 232 (Ind. 2016).

95. Id. at 232-33.

96. Id. at 236.

97. W.M. v. F.F., 55 N.E.3d 386, 389 (Ind. Ct. App.), trans. denied sub nom. D.M. v. F.F., 59 N.E.3d 251 (Ind. 2016). 